\title{
Inter-site differences in the biodynamics and body concentration of silver in a marine predatory gastropod
}

\author{
Wen-Xiong Wang*, Man Fung Tse \\ Department of Biology, The Hong Kong University of Science and Technology (HKUST), Clear Water Bay, Kowloon, \\ Hong Kong SAR
}

\begin{abstract}
The body concentrations of Ag in a top marine predator, the whelk Thais clavigera, varied significantly (1.10 to $4.67 \mathrm{\mu g} \mathrm{g}^{-1} \mathrm{dry} \mathrm{wt}$ ) in individuals collected from 3 intertidal rocky shores in Hong Kong, whereas there was no significant difference in Ag concentrations in species from lower trophic levels (macroalgae Ulva sp. and rocky oyster Saccostrea cucullata). We compared the variation in Ag biodynamics in whelks collected from these 3 locations. There was no significant difference in the Ag dietary assimilation efficiency, Ag dissolved uptake rate, or estimated metallothionein concentration among the 3 locations. Significant differences were found in the Ag efflux rate constant and the subcellular distribution of Ag. Whelks from Clear Water Bay, which had the lowest body concentration of Ag, had a higher Ag efflux rate constant $\left(0.0268 \mathrm{~d}^{-1}\right)$ than those collected from the other 2 sites ( 0.0076 to $\left.0.0095 \mathrm{~d}^{-1}\right)$, as well as a correspondingly lower fraction of Ag in the metallothionein-like protein pool (which might contain both metallothioneins and other low molecular weight thiols). The Ag distribution in the other 4 subcellular fractions (metal-rich granules, cellular debris, organelles, heatsensitive proteins) was similar among the 3 sites. The biokinetic model demonstrated that biokinetic parameters can predict this 4 -fold inter-site difference of body Ag concentrations in whelks. Moreover, such variation was mainly caused by variation in Ag efflux, although other parameters such as dietary assimilation and the concentration of Ag in prey were also important. Our calculations suggest that the prey composition may be specific to the site. The complexity of food webs should thus be considered when examining metal bioaccumulation in marine predators.
\end{abstract}

KEY WORDS: Silver $\cdot$ Whelk $\cdot$ Thais clavigera $\cdot$ Inter-site difference $\cdot$ Bioaccumulation $\cdot$ Biokinetics

\section{INTRODUCTION}

One important aspect of trace metal ecotoxicology in marine invertebrates is the notable variation in the body concentrations of these metals, which can be up to several orders of magnitude among metals and species of aquatic organisms (Eisler 1981, Rainbow 1993, Kennish 1997, Luoma \& Rainbow 2005). Recently, a biokinetic model that uses laboratory-determined biokinetic parameters of metals coupled with field measurements of the biogeochemistry of metals was developed to explain their observed body concentrations (Wang et al. 1996, Luoma \& Rainbow 2005, Wang \& Rainbow 2008). Several studies have successfully pre- dicted metal accumulation in a few marine animals, but very few studies have addressed site-specific differences in metal concentrations. The sensitivity of the biokinetic model to predict variations in metal accumulation in inter-site populations has not been tested rigorously.

Marine gastropods are an excellent taxon for studying the trophic transfer of metals (Nott \& Nicolaidou 1989, Nott 1998). They are usually the top predators in marine intertidal benthic communities, such as those found on sandy beaches and rocky shores. In these animals, food-chain transfer is a predominant route for metal accumulation, due to their slow dissolved uptake rates as well as their unusually high dietary assimila- 
tion (Wang \& Ke 2002, Blackmore \& Wang 2004a). Concentrations of several metals (e.g. Cd, Ag, Cu) can be biomagnified in intertidal rocky shore food webs (Cheung \& Wang 2008), i.e. the measured metal concentrations in the gastropod predators are higher than those in their prey (Jeng et al. 2000, Blackmore \& Morton 2001).

Ag is an important toxic metal that impacts the marine environment (Luoma et al. 1995, Ratte 1999, Andren \& Bober 2002, Gorsuch et al. 2003). Anthropogenic activities involving municipal and industrial (e.g. photography) discharge contribute to the elevated Ag concentration in coastal environments. More recently, another major concern has developed regarding $\mathrm{Ag}$ and its wide application in nanotechnology (Luoma 2008). Ag can interfere with the reproductive activity of marine bivalves (Hornberger et al. 2000, Brown et al. 2003). Cheung \& Wang (2008) found that Ag concentrations in the top marine rocky shore predator, the whelk Thais clavigera, differed significantly in different Hong Kong coastal water locations. For example, T. clavigera from Butterfly Bay on the western side of Hong Kong had a body concentration of $2.19 \mathrm{\mu g} \mathrm{Ag} \mathrm{g}^{-1}$ dry wt as compared to $0.51 \mathrm{\mu g} \mathrm{g}^{-1}$ in Clear Water Bay on the eastern side. The concentrations of other metals $(\mathrm{Cd}, \mathrm{Cu}$, and $\mathrm{Zn})$ in $T$. clavigera remained similar in whelks collected from different areas. An earlier study also found that Ag concentrations in T. clavigera from Clear Water Bay varied seasonally, with the highest concentrations in the fall to winter seasons (Wang \& Wong 2006). The biokinetic mechanisms causing the inter-site differences in $\mathrm{Ag}$ concentrations remain unexplored.

Shi \& Wang (2004) compared the body concentrations of $\mathrm{Cd}$ in 2 marine clam species, Mactra veneriformis and Ruditapes philippinarum, from locations with different contamination histories. They found that the populations with a higher $\mathrm{Cd}$ tissue concentration assimilated $\mathrm{Cd}$ more efficiently, in correlation with an increase in the $\mathrm{Cd}$ associated with the metallothionein-like protein (MTLP) fraction, whereas there was no difference in the $\mathrm{Cd}$ efflux and the clams' filtration rates. Thus, the higher Cd assimilation was partially responsible for the higher tissue concentrations of Cd. Ng \& Wang (2005a) modeled $\mathrm{Cd}$ concentrations in green mussels Perna viridis collected from 2 sites (eastern and western) in Hong Kong with contrasting hydrological conditions. Mussels from the western site had 3 to 6 times higher $\mathrm{Cd}$ tissue concentrations than did the eastern population. This difference was likely caused by the faster influx of $\mathrm{Cd}$ from the aqueous phase. These studies showed that there are different biokinetic mechanisms accounting for the inter-population variation in accumulation of $\mathrm{Cd}$.
In the present study, we examined the biokinetic mechanisms that cause the inter-site differences in the body concentrations of $\mathrm{Ag}$ in the predatory whelk Thais clavigera. The whelks were collected from 3 locations in Hong Kong and had contrasting body concentrations of Ag. We measured the dietary assimilation, dissolved uptake, and efflux rate constant for $\mathrm{Ag}$ in the 3 populations of whelks. The subcellular distribution and metallothionein concentrations of Ag were simultaneously quantified to investigate if subcellular and biochemical differences could explain the differences in Ag biokinetics. Finally, we used the biokinetic model to explain the inter-site differences.

\section{MATERIALS AND METHODS}

Field collection of organisms. Whelk, Thais clavigera (shell length: 25 to $30 \mathrm{~mm}$; dry tissue weight: $\sim 0.2 \mathrm{~g}$ ), were collected from 3 rocky shore areas: Butterfly Bay, Tung Chung Pier, and Clear Water Bay (Fig. 1). The Tung Chung Pier is next to Hong Kong International Airport on Lantau Island and experiences significant influence from the Pearl River Estuary. Butterfly Bay is on the western side of Hong Kong, which is also subjected to significant influence from the Pearl River Estuary. In contrast, Clear Water Bay is on the eastern side of Hong Kong and is mainly affected by oceanic currents. Mesogastropod snails (topshell) Monodonta labio, rocky oyster Saccostrea cucullata, and macroalgae Ulva sp. were simultaneously collected from the same sites. All collections and experimental studies were conducted from March to May 2008 in order to avoid inter-site differences in salinity, which can potentially affect the accumulation of Ag in marine species. After collection, the animals were acclimated for $2 \mathrm{wk}$ in circulating seawater at $29 \mathrm{psu}$ and $22^{\circ} \mathrm{C}$ in the laboratory before the experiments. During this period, the whelks were fed ad libitum with topshell snails M. labio (which were also used as food to quantify the dietary assimilation efficiency) and rocky oysters $S$. cucullata. All experiments were conducted at $29 \mathrm{psu}$ and $22^{\circ} \mathrm{C}$.

Body Ag and metallothionein (MT) concentration, and subcellular Ag distribution. A total of 8 individual topshells, oysters, and whelks from each population were dissected and dried at $80^{\circ} \mathrm{C}$ until constant weight was achieved; the dried tissues were subsequently digested with $70 \%$ nitric acid at room temperature for $1 \mathrm{~d}$. The samples were then heated at $50^{\circ} \mathrm{C}$ for $2 \mathrm{~h}$ and at $80^{\circ} \mathrm{C}$ for $2 \mathrm{~h}$. Finally, the samples were heated at $110^{\circ} \mathrm{C}$ until the tissues were totally digested. The concentrations of Ag were measured by a PerkinElmer AAnalyst 800 atomic absorption spectroscope after appropriate dilution. A standard reference material (oyster tissue 


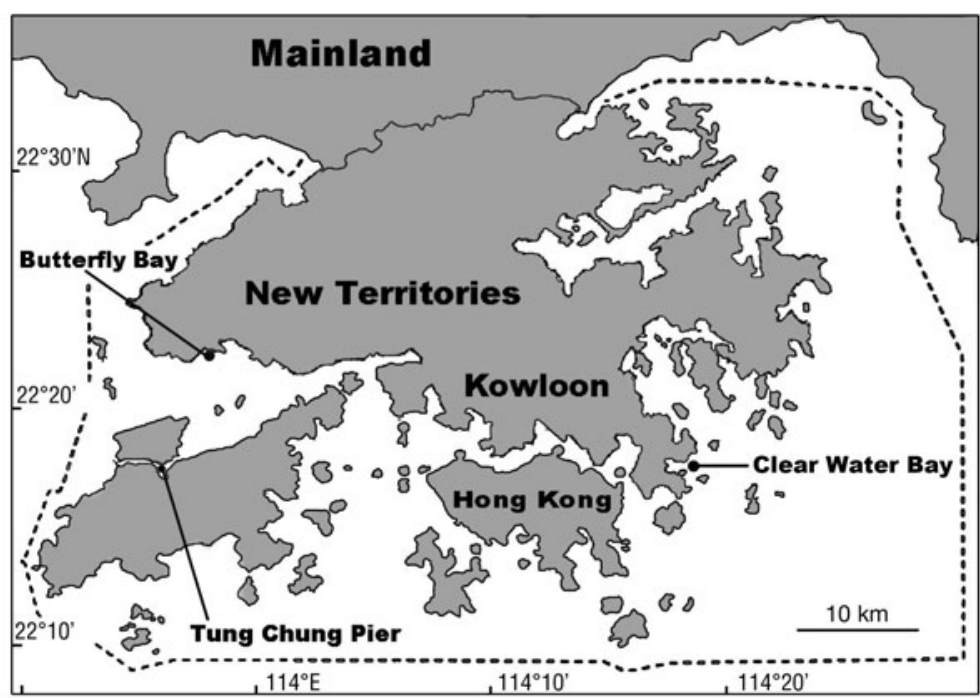

Fig. 1. The 3 sampling sites in Hong Kong coastal waters
Waterborne uptake, dietary assimilation, and efflux. A total of 8 whelks or topshells of each local population were individually placed into $500 \mathrm{ml}$ of $0.22 \mu \mathrm{m}$ filtered seawater spiked with radioisotope ${ }^{110 \mathrm{~m}} \mathrm{Ag}$ (in $0.1 \mathrm{~N} \mathrm{HCl}$ ). Radioisotope additions were of

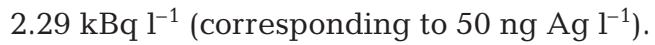
During the $12 \mathrm{~h}$ of exposure, the water was regularly stirred. Care was also taken to ensure the submergence of the gastropods in water. At 2, 4, and $8 \mathrm{~h}$ of exposure, the individual whelks or topshells were removed, radioassayed, and returned to the radioactive Ag solution for continuous exposure. At the end of exposure (12 h), the animals were radioassayed and dissected. The soft tissues were then dried at $80^{\circ} \mathrm{C}$, and the dry weights were determined. Uptake rates were calculated as the slope of the linear regression between the amount of

1566b; National Institute of Standards and Technology) was concurrently digested and analyzed for Ag concentration. The recovery of Ag was $>90 \%$.

MT concentrations in snails and whelks were estimated with a modified Ag-saturation method (Blackmore \& Wang 2004a). Briefly, the snails and whelks from each population were dissected, weighed, and homogenized with $30 \mathrm{mM}$ Tris-base buffer ( $\mathrm{pH}$ 8; $0.15 \mathrm{M}$ $\mathrm{NaCl}, 0.1 \mathrm{mM} \mathrm{PMSF}$, and $10 \mathrm{mM}$ antioxidant 2-mercaptoethanol). The homogenate was centrifuged at $4^{\circ} \mathrm{C}$ and $18000 \times g$ for $20 \mathrm{~min}$, after which $1 \mathrm{ml}$ supernatant separated from the pellet was incubated with $0.5 \mathrm{ml}$ of $20 \mu \mathrm{g} \mathrm{ml}^{-1}$ of stable $\mathrm{Ag}$ and $7.4 \mathrm{kBq}^{-1}{ }^{110 \mathrm{~m}} \mathrm{Ag}$ in $30 \mathrm{ml}$ Tris-base buffer at room temperature for $10 \mathrm{~min}$. After saturation of the MT-binding sites, $100 \mu \mathrm{l}$ rabbit $\mathrm{RBC}$ hemolysate was added to remove the excess Ag, followed by heat treatment at $100^{\circ} \mathrm{C}$ for $5 \mathrm{~min}$, and then centrifugation at $3000 \times g$ for $5 \mathrm{~min}$ at $4^{\circ} \mathrm{C}$. The procedures of hemolysate addition and heat treatment followed by centrifugation were repeated 2 more times, after which the supernatant was removed for radioactivity measurement.

Another 4 whelks from each population were dissected, and their subcellular distributions of Ag were measured using the methods described by Wallace et al. (2003). A total of 5 different fractions were obtained, including the cellular debris, metal-rich granules (MRG), organelles, heat-sensitive proteins (HSP), and MTLP fractions (which might contain both metallothioneins and other low molecular weight thiols such as glutathione). These 5 fractions were dried at $80^{\circ} \mathrm{C}$ and then digested with $70 \%$ nitric acid at $80^{\circ} \mathrm{C}$ until clear. Subsequently, the concentrations of $\mathrm{Ag}$ in all 5 fractions were measured by atomic absorption spectrometry after appropriate dilution.
Ag accumulated by the soft tissues and the time of exposure.

To measure the dietary Ag assimilation, the topshells were first radiolabeled with aqueous $37 \mathrm{kBq} \mathrm{l}^{-1}$ of ${ }^{110 \mathrm{~m}} \mathrm{Ag}$ for $7 \mathrm{~d}$. After exposure, the topshells were dissected and fed to the whelks for subsequent Ag assimilation and efflux experiments. The whelks were placed in $200 \mathrm{ml}$ of $0.22 \mu \mathrm{m}$ filtered seawater and allowed to feed on the radiolabeled topshells for $1 \mathrm{~h}$. The whelks were then radioassayed and transferred to $200 \mathrm{ml}$ of seawater to depurate the ingested food for $48 \mathrm{~h}$. During the depuration period, the whelks were fed nonradiolabeled topshell tissues, and the feces were removed to minimize the recycling of metals. The radioactivity was assayed at 3 to $12 \mathrm{~h}$ intervals over the $48 \mathrm{~h}$ depuration period. Water was renewed after every radioassay. The assimilation efficiency (AE) was calculated as the percentage of initial radioactivity retained in whelks after $48 \mathrm{~h}$ of depuration.

The efflux rate constant of Ag in the whelks was measured following uptake from the dietary phase; 10 individual whelks were placed in 21 of $0.22 \mu \mathrm{m}$ filtered seawater and fed ${ }^{110 \mathrm{~m}} \mathrm{Ag}$ radiolabeled topshells. Water was renewed every day, and the whelks were fed for $7 \mathrm{~d}$. After radioactive feeding, the whelks were placed in nonradiolabeled water for $12 \mathrm{~h}$ to evacuate the ingested radiolabeled food. They were then rinsed with filtered water, and the radioactivity was immediately measured. Afterwards, they were allowed to depurate in aerated, nonradioactive seawater for $15 \mathrm{~d}$, during which the whelks were fed nonradioactive topshells on a daily basis, and the water was changed every $2 \mathrm{~d}$ to minimize the build-up of radioisotopes in the water. Any feces were removed every $12 \mathrm{~h}$ to minimize the recycling of metals. The radioactivity re- 
maining in the animals was measured at 12 to $48 \mathrm{~h}$ intervals. By the end of $15 \mathrm{~d}$ of depuration, the whelks were radioassayed.

Differences in biokinetic parameters among the 3 populations of whelks were first tested by 1-way ANOVA with a least-significant-difference post hoc test, in which all the percentage data were arcsine transformed before analysis.

\section{RESULTS AND DISCUSSION}

\section{Ag and MT concentrations, and subcellular Ag distribution}

The Ag concentrations in the macroalgae from Butterfly and Clear Water Bays were relatively low $(0.08-$

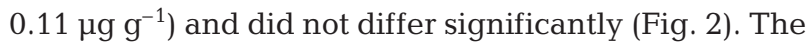
oyster Ag concentrations were also not significantly different among the 3 sites (0.66-0.81 $\mu^{-1} \mathrm{~g} \mathrm{~g}^{-1}$ (Fig. 2). In contrast, the Ag concentrations in the topshells were significantly higher in topshells from Tung Chung and Butterfly Bay $\left(2.05-2.91 \mathrm{\mu g} \mathrm{g}^{-1}\right)$ than that from the Clear Water Bay (1.12 $\mu \mathrm{g} \mathrm{g}^{-1}$ ) (Fig. 2). The Ag concentrations in the whelks also differed significantly among the three sites. The concentration of Ag in the whelks from Tung Chung $\left(4.67 \mu^{-1} \mathrm{~g}^{-1}\right)$ was greater than that in the whelks from Butterfly Bay $\left(2.86 \mu \mathrm{g} \mathrm{g}^{-1}\right)$, which was greater than that from in the whelks from Clear Water Bay $\left(1.10 \mu \mathrm{g} \mathrm{g}^{-1}\right)$. Overall, the body concentrations of Ag in the whelks varied by a factor of 4.2 (Fig. 2).

The body Ag concentrations measured in this study were higher than the previous measurements in Clear Water Bay and Butterfly Bay conducted in 2004 (0.03, $0.42,0.41$, and $0.51 \mathrm{ug} \mathrm{g}^{-1}$ for Ulva, Saccostrea cucullata, Monodonta labio, and Thais clavigera from Clear Water Bay, respectively, and 0.07, 0.87, 0.86, and $2.19 \mathrm{\mu g} \mathrm{g}^{-1}$ from Butterfly Bay, respectively, Cheung and Wang 2008). With the exception of oysters from Butterfly Bay, the present measurements were 1.3 to 2.7 times higher than those quantified in 2004. The reasons for this inter-annual difference are unknown, but they may reflect an increasing input of Ag into the local environments, or they may be due to the seasonal variation of metal concentrations, which was well documented in the previous study. Wang \& Wong (2006) found that the Ag concentrations in the rocky shore from Clear Water Bay exhibited strong seasonal variation, in contrast to other metals such as $\mathrm{Cu}, \mathrm{Cd}$, and $\mathrm{Zn}$. For example, whelks had the highest Ag concentrations $\left(10 \mu \mathrm{g} \mathrm{g}^{-1}\right)$ during October and December, and the lowest concentrations $\left(1 \mu \mathrm{g} \mathrm{g}^{-1}\right)$ in June to August. It is not clear whether this variation was caused by the reproductive activities of the whelks.

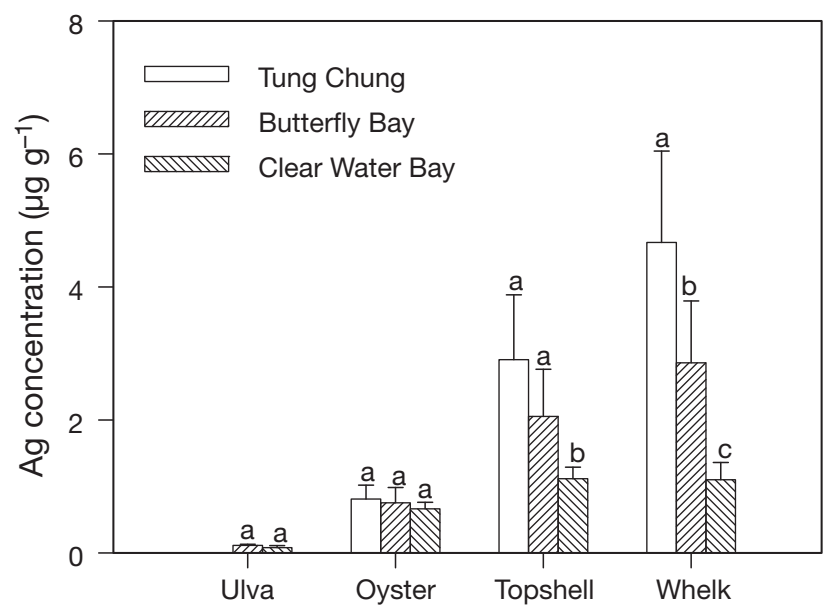

Fig. 2. Ag tissue concentrations in the macroalgae Ulva sp., rocky oysters Saccostrea cucullata, topshells Monodonta labio, and whelks Thais clavigera collected from the 3 sites in Hong Kong. Data are mean \pm SD $(n=8)$. Different letters within each site show statistically significant difference $(p<0.05)$

We did not measure the dissolved Ag concentration in the present study. $\mathrm{Ng} \&$ Wang (2005b) found that the dissolved Ag concentrations in Tung Chung (1 of the sampling sites in the present study) and Tolo Harbour were below the detection limit $\left(0.005 \mu \mathrm{g} \mathrm{l}^{-1}\right)$. Since there was no notable difference in Ag concentrations in the macroalgae (in which the only source of $\mathrm{Ag}$ uptake is from the dissolved phase) or in the oysters (in which both the dissolved phase and particles can contribute to Ag accumulation) among the 3 sites, it is likely that the dissolved Ag concentrations were similar.

The MT concentrations in the whelks were similar (despite the significant variation in body concentrations of Ag) among the 3 locations ( $p>0.05$; Fig. 3), and they were much lower than those in the topshells. There is no report on Ag induction of MT in marine gastropods, but Ag induction of MT in other marine invertebrates varies widely among species (Amiard et al. 2006). Furthermore, many environmental factors in addition to metals may affect MT concentrations (Leung \& Furness 1999, Mouneyrac et al. 2000). Using MT as a biomarker for metal exposure in the field requires careful assessment. In marine bivalves, Ag may bind with MRGs as an Ag sulfide complex (Berthet et al. 1992).

In contrast to $\mathrm{MT}$, the subcellular distribution of $\mathrm{Ag}$ in MTLP was significantly lower in Clear Water Bay whelks (11\%) than in Tung Chung and Butterfly Bay whelks (18 to 19\%) (Fig. 4). No significant difference was found among the 3 locations in the other subcellular fractions (MRG, cellular debris, organelles, HSP). About 38 to $44 \%$ of Ag was in the MRG fraction, 20 to $28 \%$ in the cellular debris fraction, and 5 to $8 \%$ of $\mathrm{Ag}$ 


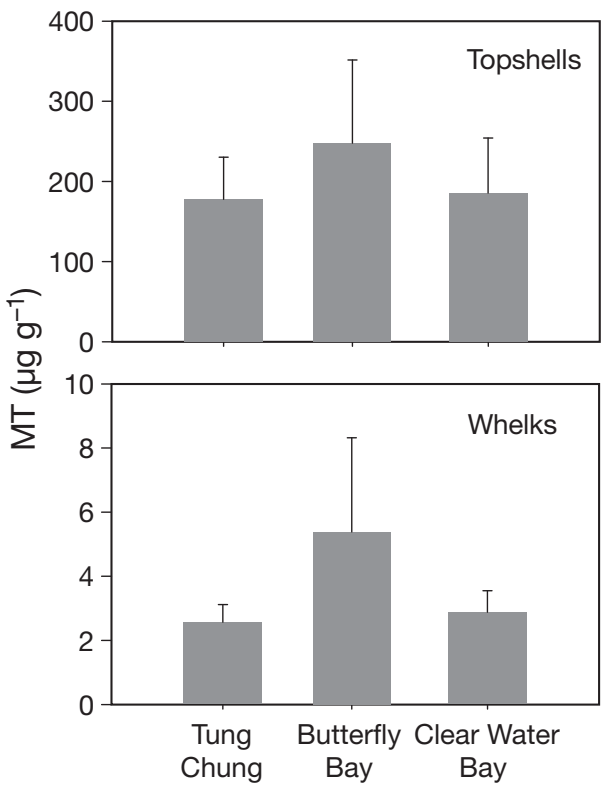

Fig. 3. Monodonta labio and Thais clavigera. Metallothionein (MT) concentrations in topshells and whelks collected from the 3 sites in Hong Kong. Data are mean + SD $(n=4)$

in HSP. As in many other invertebrates (Bustamante \& Miramand 2005), Ag was mostly stored in MRG and cellular debris, but it is clear that a significant fraction of Ag was indeed associated with MTLP in whelks.

\section{Ag biokinetics}

The dietary AE in the whelks was measured by pulse feeding them radiolabeled topshells for $1 \mathrm{~h}$, followed by depuration for $3 \mathrm{~d}$ (Fig. 5). Depuration of $\mathrm{Ag}$ appeared to level off after $2 \mathrm{~d}$, and there were notable differences in the depuration from the 3 locations. The $\mathrm{AE}$ was calculated as the percentage of Ag remaining in the whelks after $2 \mathrm{~d}$ of depuration (Table 1). Whelks from Clear Water Bay had a significantly lower AE (46\%) as compared to whelks from Tung Chung and Butterfly Bay (68 to $77 \%$ ). AEs of other metals, such as

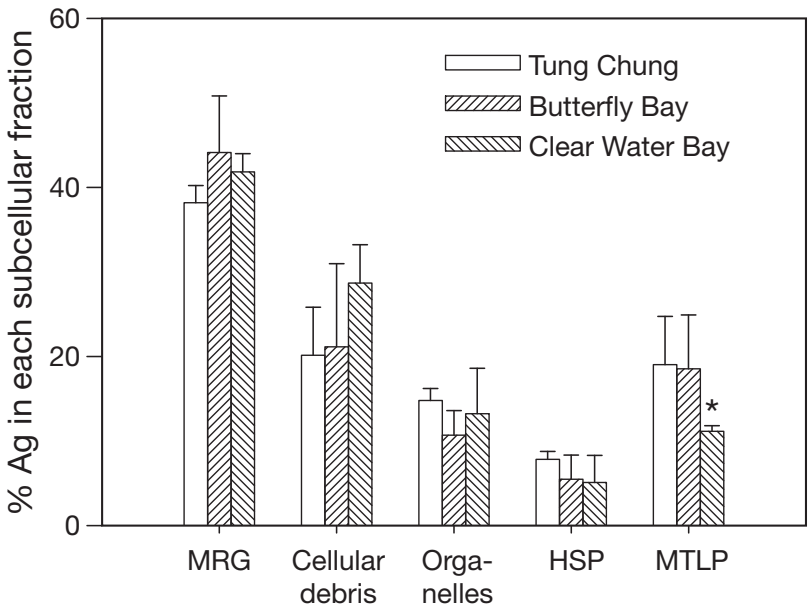

Fig. 4. Thais clavigera. Ag in different subcellular fractions of whelks collected from the 3 sites in Hong Kong. MRG: metalrich granules, HSP: heat-sensitive protein, MTLP: metallothionein-like protein. Data are mean + SD $(n=3)$. Asterisk indicates significant difference from the other 2 sites

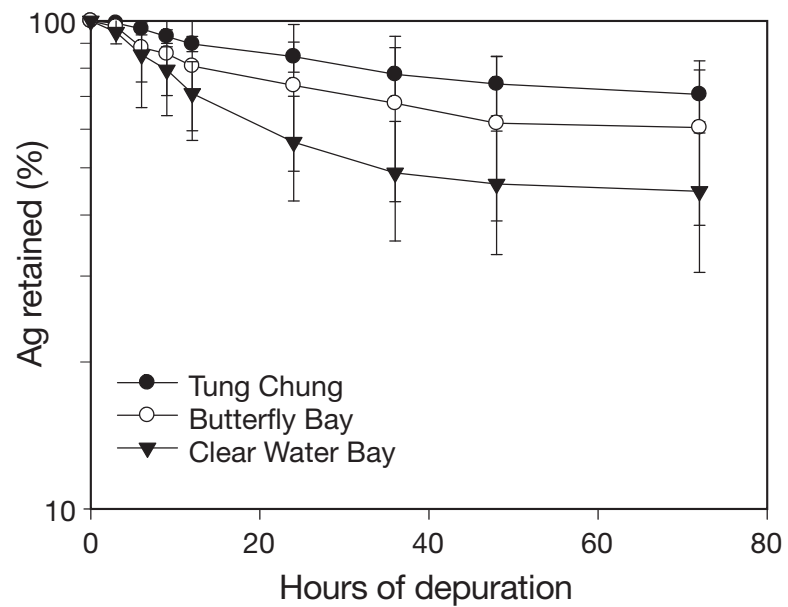

Fig. 5. Thais clavigera. Ag retention in whelks collected from the 3 sites in Hong Kong following pulse ingestion of radio labeled prey. Data are mean \pm SD $(n=8)$

Table 1. Thais clavigera and Monodonta labio. A summary of the biokinetic parameters in whelks and topshells collected from 3 sites in Hong Kong. Different letters show statistically significant differences $(p<0.05)$ between sites. Data are mean \pm SD $(n=8)$

\begin{tabular}{|llcccc|}
\hline & & Tung Chung & Butterfly Bay & Clear Water Bay \\
\hline \multirow{2}{*}{ Thais clavigera } & Assimilation efficiency $(\%)$ & $77.0 \pm 5.8^{\mathrm{A}}$ & $67.6 \pm 14.0^{\mathrm{A}}$ & $46.3 \pm 14.7^{\mathrm{B}}$ \\
& Dissolved uptake rate $\left(\mathrm{ng} \mathrm{g}^{-1} \mathrm{~h}^{-1}\right.$ & 0.613 & 0.777 & 0.461 \\
& Dissolved uptake rate constant $k_{\mathrm{u}}\left(\mathrm{l} \mathrm{g}^{-1} \mathrm{~d}^{-1}\right)$ & 0.294 & 0.373 & 0.221 \\
& Efflux rate constant $k_{\mathrm{e}}\left(\mathrm{d}^{-1}\right)$ & $0.0076 \pm 0.0051^{\mathrm{A}}$ & $0.0095 \pm 0.0035^{\mathrm{A}}$ & $0.0268 \pm 0.0106^{\mathrm{B}}$ \\
\multirow{2}{*}{ Monodonta labio } & Dissolved uptake rate $\left(\mathrm{ng} \mathrm{g}^{-1} \mathrm{~h}^{-1}\right)$ & 1.254 & 1.307 & 1.138 \\
& & & &
\end{tabular}


$\mathrm{Cd}$ and $\mathrm{Zn}$, are much higher in these predatory gastropods (Blackmore \& Wang 2004b, Cheung \& Wang 2005). One reason for high metal $\mathrm{AE}$ is the feeding physiology of predatory gastropods. Whelks use their proboscis to digest food materials extracellularly before final ingestion (Rainbow et al. 2007). Since only 3 populations of whelks were examined in the present study and the Ag AEs were generally high, it is difficult to conclude that the Ag AE is related to its subcellular fractionation. Blackmore \& Wang (2004b) fed radiolabeled mussels, barnacles, topshells, and oysters to whelks and examined the relationship between the AEs of $\mathrm{Cd}$ and $\mathrm{Zn}$ and their subcellular distribution in the soluble fraction in the prey. They did not find a significant correlation, mainly because the AEs of $\mathrm{Cd}$ and $\mathrm{Zn}$ in the whelks were high (>65\%).

The uptake rates of Ag from the dissolved phase by both topshells and whelks are shown in Fig. 6. Generally, a linear pattern of uptake occurred between 2 and $12 \mathrm{~h}$ of exposure, and the uptake rate was therefore calculated from the linear regression of the Ag accumulation versus the time of exposure ( 2 to $12 \mathrm{~h}$ ). There were rather large individual variations in Ag accumulation for each site population, but the overall calculated uptake rates of $\mathrm{Ag}$ did not differ significantly among the 3 different populations (Table 1). Furthermore, the uptake rate constant was calculated as the uptake rate divided by the dissolved exposed Ag con-

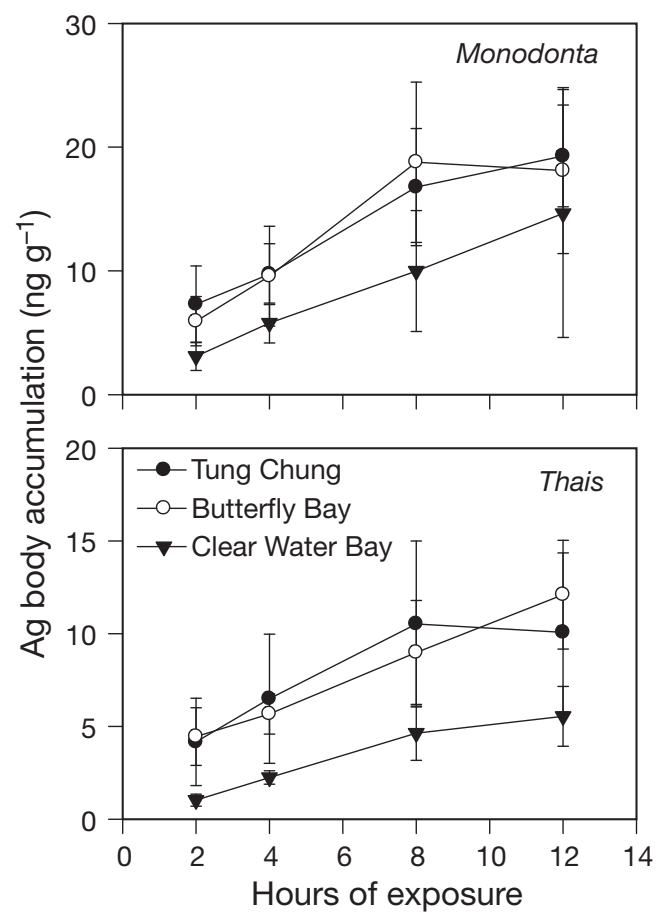

Fig. 6. Monodonta labio and Thais clavigera. The accumulation of Ag in topshells and whelks collected from the 3 sites in Hong Kong during exposure to aqueous Ag. Data are mean $\pm \mathrm{SD}(\mathrm{n}=8)$ centrations. Accordingly, the Ag uptake rate constant was from 0.221 to $0.373 \mathrm{l} \mathrm{g}^{-1} \mathrm{~d}^{-1}$ for whelks and from 0.546 to $0.627 \mathrm{~g} \mathrm{~g}^{-1} \mathrm{~d}^{-1}$ for topshells. These dissolved Ag uptake rate constants were higher than those measured for other metals in the same whelk species (Hg[II]: $0.079 \mathrm{l} \mathrm{g}^{-1} \mathrm{~d}^{-1}, \mathrm{MeHg}: 0.108 \mathrm{l} \mathrm{g}^{-1} \mathrm{~d}^{-1}, \mathrm{Cd}: 0.030$ $1 \mathrm{~g}^{-1} \mathrm{~d}^{-1}$, and Zn: $0.069 \mathrm{l} \mathrm{g}^{-1} \mathrm{~d}^{-1}$; Blackmore \& Wang 2004b), but they were much lower than those measured in filter-feeding bivalves (Wang et al. 1996).

Ag depuration following $7 \mathrm{~d}$ of dietary exposure in the whelks is shown in Fig. 7. Whelks from Clear Water Bay depurated $\mathrm{Ag}$ at a much higher rate than did whelks from Tung Chung and Butterfly Bay. About $51 \%$ of Ag remained in the whelks after $15 \mathrm{~d}$ of depuration in the Clear Water Bay group, while 71 to $76 \%$ of Ag remained in the whelks from the other 2 sites. Ag depuration was characterized by an initial loss and then a second compartmental loss. The efflux rate constant calculated from the slope of the loss from Day 7 onward differed significantly among the 3 locations (Table 1). Whelks collected from Clear Water Bay had a significantly higher $\left(0.0268 \mathrm{~d}^{-1}\right)$ efflux rate constant than did whelks from Tung Chung and Butterfly Bay $\left(0.0076\right.$ to $\left.0.0095 \mathrm{~d}^{-1}\right)$.

Since whelks from only 3 sites were examined, it is difficult to conclude that the difference in Ag efflux was due to the difference in the subcellular partitioning of Ag in the whelks. Although there were no major differences in the Ag in MRG, cellular debris, organelles, and HSP, the distribution of Ag in MTLP was lower in the Clear Water Bay whelks $(11 \%)$ than in the Tung Chung and Butterfly Bay whelks (18 to $19 \%$ ). Whether a lower fraction of Ag in MTLP can result in a greater efflux of Ag still needs to be further tested, especially in marine gastropods. Ng \& Wang (2005c) found that mussels displayed a dynamic pattern of metal distribution over $28 \mathrm{~d}$ of depuration, and high Ag retention was related to high Ag in the insoluble fraction and low Ag in the MTLP fraction. The increase of Ag in the insoluble fraction over the depuration period was probably caused by the faster elimination of $\mathrm{Ag}$ from the other fractions (e.g. MTLP).

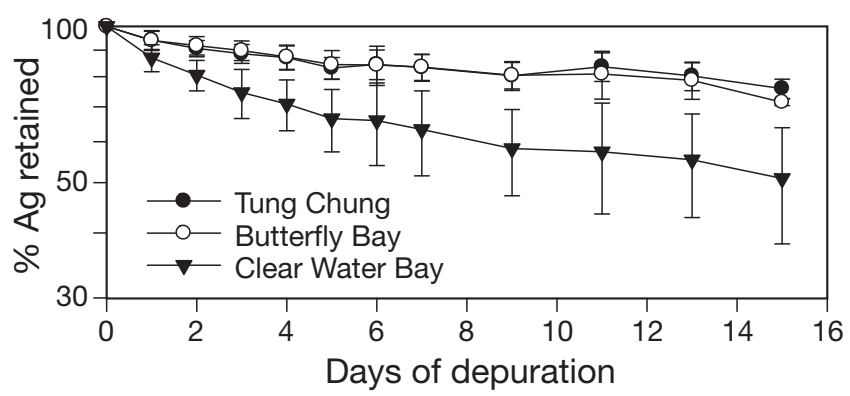

Fig. 7. Thais clavigera. Ag retention in whelks collected from the 3 sites in Hong Kong following 7 d of ingestion of radiolabeled prey. Data are mean $\pm \mathrm{SD}(\mathrm{n}=8)$ 
In another study, $\mathrm{Ng} \&$ Wang (2005b) examined the roles of subcellular distribution in Ag accumulation and elimination in the green mussel Perna viridis from 2 hydrographical zones (harbor vs. estuarine) in Hong Kong. They found that the percentage of Ag in the HSPs correlated positively to Ag efflux, and a higher percentage of Ag in the insoluble fraction was related to lower assimilation. More recently, Pan \& Wang (2009) reported a significant correlation between newly accumulated $\mathrm{Cu}$ in the MTLP fraction and the efflux rate in 5 species of marine bivalves, the scallop Chlamys nobilis, the clam Ruditapes philippinarum, the green mussel $P$. viridis, the black mussel Septifer virgatus, and the oyster $S$. cucullata, suggesting that MTLP may be responsible for $\mathrm{Cu}$ elimination and may control $\mathrm{Cu}$ regulation in bivalves. These data on marine bivalves indicate that MTLP may facilitate metal efflux as a result of MT turnover (synthesis and breakdown).

\section{Modeling Ag body concentration in whelks}

We sought to explain the inter-site difference of Ag concentrations in whelks using biokinetic modeling. The Ag concentrations in the whelks under steadystate conditions $\left(C_{\mathrm{ss}}\right)$ can be predicted by the following equation (Wang et al. 1996):

$$
C_{\mathrm{ss}}=\left(k_{\mathrm{u}} \times C_{\mathrm{w}}+\mathrm{AE} \times \mathrm{IR} \times C_{\mathrm{f}}\right) / k_{\mathrm{e}}
$$

where $k_{\mathrm{u}}$ is the dissolved uptake rate constant, $C_{\mathrm{w}}$ is the Ag concentration in the dissolved phase $\left(\mu \mathrm{g} \mathrm{l}^{-1}\right)$, IR is the ingestion rate of whelks, $C_{\mathrm{f}}$ is the Ag concentration in ingested food and $k_{\mathrm{e}}$ is the efflux rate constant. Since the dissolved uptake rate is much lower than that from trophic transfer (Wang \& Ke 2002, Blackmore \& Wang 2004b), this equation can be further simplified to include only the dietary exposure term:

$$
C_{\mathrm{ss}}=\mathrm{AE} \times \mathrm{IR} \times C_{\mathrm{f}} / k_{\mathrm{e}}
$$

We used an average daily IR of $5 \%$ in our model calculations (Blackmore \& Wang 2004b). The averaged $\mathrm{AE}, C_{\mathrm{f}}$, and $k_{\mathrm{e}}$ were taken from the present study, with the assumption that oysters and topshells were the diets of whelks. The predicted body concentrations of Ag, as well as the actual Ag concentrations in the whelks, are shown in Fig. 8. Predicted body concentrations of Ag in whelks from Tung Chung and Butterfly Bay are essentially the same as the actual measurements when oysters are the prey for whelks. If topshells are the prey, the predicted concentrations are 2.6 to 3.2 times higher than the actual concentrations. The main prey from these 2 sites was likely oysters. In the Clear Water Bay whelks, the predicted concentration was $0.57 \mu \mathrm{g} \mathrm{g}^{-1}$ (oyster as prey) or $0.96 \mu \mathrm{g} \mathrm{g}^{-1}$ (topshells as prey), as compared to $1.10 \mu \mathrm{g} \mathrm{g}^{-1}$ in the actual measurements.
Blackmore (2000) illustrated the importance of prey selection in determining body concentrations of metals $(\mathrm{Cd}, \mathrm{Cu}$, and $\mathrm{Zn})$ in whelks. Whelks from an exposed shore where barnacles Tetraclita squamosa dominated the diet had high body concentrations of $\mathrm{Zn}$, due to the high concentrations of $\mathrm{Zn}$ in the barnacles. In contrast, whelks from a sheltered shore had high body concentrations of $\mathrm{Cu}$, due to the dominance of gastropods in their diet. Clearly, the body concentrations of metals in predators are highly dependent on their concentrations in prey. It will be particularly interesting to explore the possibility of using accumulated metal body burden to trace the prey composition of whelks in the natural environment.

Our calculation illustrates that trophic transfer can explain a 4.2-fold inter-site variation of body accumulation of Ag in predators (1.10 to $4.67 \mu \mathrm{g} \mathrm{g}^{-1}$ ). Predicted concentrations are similar to the actual measurements, adding to a growing body of evidence for the applicability of biokinetic modeling in predicting metal concentrations in aquatic animals (Wang et al. 1996, Luoma \& Rainbow 2005). In our study, the main contributor to the inter-site difference is the Ag efflux rate, which varied by a factor of 3.5. The AE and prey Ag concentration played a less important role in determining differences in body concentrations of Ag. The body concentrations of Ag in whelks from Tung Chung and Butterfly Bay differed significantly, whereas there was only a slightly higher AE and prey Ag concentration and a slightly lower efflux rate in the whelks from Tung Chung.

In an earlier study, $\mathrm{Ng} \&$ Wang (2005b) examined estuarine and harbor mussels (Perna viridis) with contrasting Ag accumulation strategies. The harbor

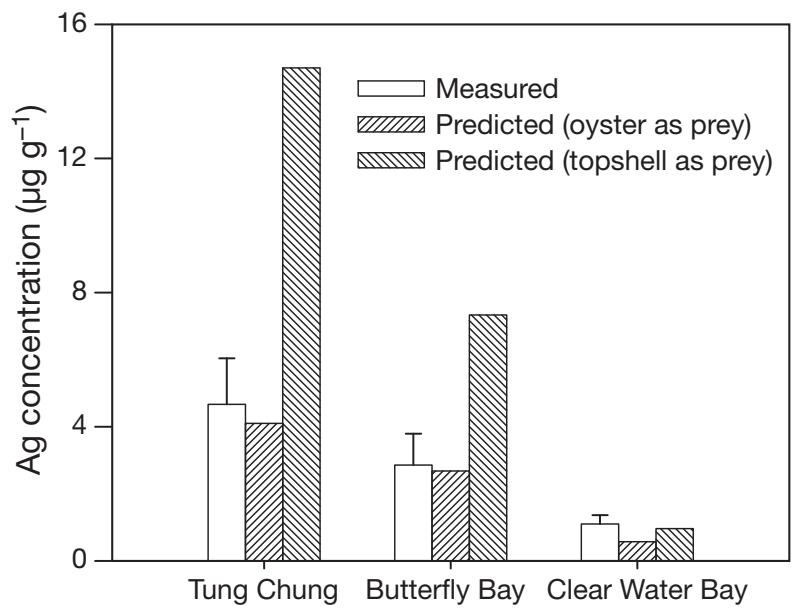

Fig. 8. Thais clavigera. Comparison of the predicted and measured body concentrations of Ag in whelks collected from the 3 sites in Hong Kong. The prediction assumes both oysters Saccostrea cucullata and topshells Monodonta labio as prey for the whelks. Data are mean $+\mathrm{SD}$ 
population accumulated more Ag than the estuarine population, and this pattern was found to be almost consistent in all seasons. They showed that both Ag geochemistry and metal physiology (Ag uptake and loss kinetics) explain the observed differences in the body burdens between the 2 populations. The calculations indicated that the predicted Ag concentrations in the harbor mussels $\left(0.10\right.$ to $\left.0.53 \mathrm{\mu g} \mathrm{g}^{-1}\right)$ were indeed very close to the measured Ag concentrations in mussels $\left(0.21\right.$ to $\left.0.29 \mu \mathrm{g} \mathrm{g}^{-1}\right)$. At the estuarine location, however, the predicted Ag concentrations (0.37 to $0.55 \mu \mathrm{g} \mathrm{g}^{-1}$ ) were about 2.8- to 10-fold higher than the actual measurements ( 0.056 to $0.172{\mu g ~ g^{-1}}^{-1}$. A difference in Ag biokinetics may partially account for the interpopulation differences in Ag bioaccumulation in green mussels.

\section{CONCLUSIONS}

Body concentrations of Ag in whelks varied by a factor of $>4.2$ among the 3 sampling sites in the Hong Kong coastal marine environment, but the dissolved Ag concentrations were similar. By conducting biokinetic measurements of $\mathrm{Ag}$, we showed that dietary $\mathrm{Ag} \mathrm{AE}$ and dissolved uptake did not vary significantly, whereas the Ag efflux rate was highest in whelks from Clear Water Bay, where the Ag body concentration was also the lowest. Correspondingly, a much lower fraction of Ag was detected in the MTLP fraction in the whelks from Clear Water Bay as compared to those from the other 2 sites. The biokinetic model predicted the 4-fold inter-site difference in Ag body concentration in whelks. It is clear that the efflux of metals is critical in determining the inter-site differences of metal concentrations in whelks. The present study also has significant implications for biomonitoring programs in which biomonitors should be able to clearly reflect metal bioavailability in the ambient environment. The trophic transfer process may potentially confound the relationship between metal concentrations in biomonitors and in environments, especially when top predators are used as biomonitors of metal contamination.

Acknowledgements. We are grateful to the anonymous reviewers for their comments on this work. This study was supported by a General Research Fund from the Hong Kong Research Grants Council (HKUST6420/06M) to W.X.W.

\section{LITERATURE CITED}

Amiard JC, Amiard-Triquet C, Barka S, Pellerin J, Rainbow PS (2006) Metallothioneins in aquatic invertebrates: their role in metal detoxification and their use as biomarkers. Aquat Toxicol 76:160-202

Andren AW, Bober TW (2002) Silver in the environment: transport, fate and effects. SETAC Press, Pensacola, FL Berthet B, Amiard JC, Amiard-Triquet C, Martoja M, Jeantet AY (1992) Bioaccumulation, toxicity and physico-chemical speciation of silver in bivalve molluscs: ecotoxicological and health consequences. Sci Total Environ 125:97-122

Blackmore G (2000) Field evidence of metal transfer from invertebrate prey to an intertidal predator, Thais clavigera (Gastropoda: Muricidae). Estuar Coast Shelf Sci 51:127-139

Blackmore G, Morton B (2001) The interpretation of body trace metal concentration in neogastropods from Hong Kong. Mar Pollut Bull 42:1161-1168

Blackmore G, Wang WX (2004a) Relationship between metallothioneins and metal accumulation in the whelk Thais clavigera. Mar Ecol Prog Ser 277:135-145

Blackmore G, Wang WX (2004b) The transfer of cadmium, mercury, methylmercury, and zinc in an intertidal rocky shore food chain. J Exp Mar Biol Ecol 307:91-110

Brown CL, Parchaso F, Thompson JK, Luoma SN (2003) Assessing toxicant effects in a complex estuary: a case study of effects of silver on reproduction in the bivalve, Potamocorbula amurensis, in San Francisco Bay. Hum Ecol Risk Assess 9:95-119

> Bustamante P, Miramand P (2005) Subcellular and body distributions of 17 trace elements in the variegated scallop Chlamys varia from the French coast of the Bay of Biscay. Sci Total Environ 337:59-73

Cheung M, Wang WX (2005) Influence of subcellular metal compartmentalization in different prey on the transfer of metals to a predatory gastropod. Mar Ecol Prog Ser 286: $155-166$

Cheung MS, Wang WX (2008) Analyzing biomagnification of metals in different marine food webs using nitrogen isotopes. Mar Pollut Bull 56:2082-2088

Eisler R (1981) Trace metal concentrations in marine organisms. Pergamon Press, New York

Gorsuch JW, Kramer JR, La Point TW (2003) Silver: environmental transport, fate, effects, and models. Papers from Environmental Toxicology and Chemistry, 1983-2002. SETAC Press, Pensacola, FL

Hornberger MI, Luoma SN, Cain DJ, Parchaso F and others (2000) Linkage of bioaccumulation and biological effects to changes in pollutant loads in south San Francisco Bay. Environ Sci Technol 34:2401-2409

Jeng MS, Heng WL, Hung TC, Yeh CY, Tseng RJ, Meng PJ, Han BC (2000) Mussel watch: a review of $\mathrm{Cu}$ and other metals in various marine organisms in Taiwan, 1991-1998. Environ Pollut 110:207-215

Kennish MJ (1997) Practical handbook of estuarine and marine pollution. CRC Press, Boca Raton, FL

> Leung KMY, Furness RW (1999) Effects of animal size on concentrations of metallothionein and metals in periwinkles Littorina littorea collected from the Firth of Clyde, Scotland. Mar Pollut Bull 39:126-136

Luoma SN (2008) Silver nanotechnologies and the environment: old problems or new challenges? Woodrow Wilson International Center for Scholars, The PEW Charitable Trusts, PEN 15

Luoma SN, Rainbow PS (2005) Why is metal bioaccumulation so variable? Biodynamics as a unifying concept. Environ Sci Technol 39:1921-1931

> Luoma SN, Ho YB, Bryan GW (1995) Fate, bioavailability and toxicity of silver in estuarine environments. Mar Pollut Bull 31:44-54

> Mouneyrac C, Geffard A, Amiard J, Amiard-Triquet C (2000) Metallothionein-like proteins in Macoma balthica: effects of metal exposure and natural factors. Can J Fish Aquat Sci $57: 34-42$ 
Ng TYT, Wang WX (2005a) Modeling Cd bioaccumulation in two populations of the green mussel Perna viridis. Environ Toxicol Chem 24:2299-2305

Ng TYT, Wang WX (2005b) Subcellular controls of silver biokinetics in the green mussel Perna viridis from two hydrographic zones. Mar Ecol Prog Ser 299:193-204

Ng TYT, Wang WX (2005c) Dynamics of metal subcellular distribution and its relationship with metal uptake in marine mussels. Environ Toxicol Chem 24:2365-2372

Nott JA (1998) Metals and marine food chains. In: Langston WJ, Bebianno MJ (eds) Metal metabolism in aquatic environments. Chapman \& Hall, London, p 387-414

Nott JA, Nicolaidou A (1989) Metals in gastropods: metabolism and bioreduction. Mar Environ Res 28:201-205

Pan K, Wang WX (in press) Biodynamics to explain the difference of copper body concentrations in five marine bivalve species. Environ Sci Technol 43:2137-2143

Rainbow PS (1993) The significance of trace metal concentrations in marine invertebrates. In: Dallinger R, Rainbow PS (eds) Ecotoxicology of metals in invertebrates. Lewis Publishers, Boca Raton, FL, p 4-23

Rainbow PS, Amiard JC, Amiard-Triquet C, Cheung MS, Zhang L, Zhong H, Wang WX (2007) Trophic transfer of trace metals: subcellular compartmentalization in bivalve

Editorial responsibility: Matthias Seaman, Oldendorf/Luhe, Germany prey, assimilation by a gastropod predator and in vitro digestion simulation. Mar Ecol Prog Ser 348:125-138

Ratte HT (1999) Bioaccumulation and toxicity of silver compounds: a review. Environ Toxicol Chem 18:89-108

Shi DL, Wang WX (2004) Understanding the differences in Cd and $\mathrm{Zn}$ bioaccumulation and subcellular storage among different populations of marine clams. Environ Sci Technol 38:449-456

> Wallace WG, Lee BG, Luoma SN (2003) Subcellular compartmentalization of $\mathrm{Cd}$ and $\mathrm{Zn}$ in two bivalves. I. Significance of metal-sensitive fractions (MSF) and biologically detoxified metal (BDM). Mar Ecol Prog Ser 249:183-197

- Wang WX, Ke C (2002) Dominance of dietary intake of cadmium and zinc by two marine predatory gastropods. Aquat Toxicol 56:153-165

Wang WX, Rainbow PS (2008) Comparative approach to understand metal accumulation in aquatic animals. Comp Biochem Physiol C Toxikol Pharmacol 148:315-323

Wang WX, Wong P (2006) Dynamics of trace metal concentrations in an intertidal rocky shore food chain. Mar Pollut Bull 52:332-337

Wang WX, Fisher NS, Luoma SN (1996) Kinetic determinations of trace element bioaccumulation in the mussel, Mytilus edulis. Mar Ecol Prog Ser 140:91-113

Submitted: March 10, 2009; Accepted: April 27, 2009

Proofs received from author(s): June 3, 2009 